De Grandis (9) and Nagatomo and Aizawa (10) reported that SDH activity in inflamed tissues is increased. It is also known that the size of mitochondria in rat normal tissues varies (11). SDH activity in $600 \times \mathrm{g}$ sup which contains all sizes of mitochondria was markedly increased by serotonin, but the activity in $12,000 \times \mathrm{g}$ ppt was not changed. It was expected that SDH activity of unprecipitated mitochondria at $12,000 \% \mathrm{~g}$ (light mitochondria) would be changed by serotonin. But the increase of SDH activity by serotonin was not observed when it was measured in hypotonic medium which may swell and rupture mitochondria $(12,13)$. Therefore, the amount of SDH in mitochondria may be unchanged by serotonin (13-15). These results suggest that the mitochondrial membrane perneability for substrate, especially succinate, might change with local administration of serotonin. In the present experiment, it was demonstrated that intramuscular injection of serotonin increased SDH aclivity in the injected muscle just as was observed when dextran was used as the phlogistic (1). These data collectively indicate that an increase in SDH activity induced by serotonin injection is not specific for serotonin but may be related to the nature of "inflammatory response" in the rat.

\title{
REFERENCES
}

1) Arai, Y. And Aizawn, Y.: Folia pharmacol.japon. 69, 153p (1973) (in Japanese); 2) GaratTini, S., Jort, A., Bernard. D., Carrara, C., Paglialunga, S., and Serge, D.: International Symposium on Non-steroidal Ani-inflammatory Drugs, Edited by Garattin, S. M.N.G. Dukes, p. 151 Excepta Medica Foundation, Amsterdam (1965): 3) Witer, C.A.: International Symposimm on Non-steroidal Anti-inflammatory Drugs, Edited by Garattini, S. M.N.G. Dukes, p. 190 Excepta Medica Foundation Amsterdam (1965); 4) SChntider, W.C. AND Potter, V.R.: $J$. biol. Chem. 149, 217 (1943): 5) Straub, F.B.: Biochem. J. 34, 483 (1940): 6) Gieson, D.M., Davisson, E.O., BachHawt, B.K., Ray, B.R., AND VisIling, C.S., J. biol. Chem. 203, 397 (1953); 7) Tainka, R. and StricktLand, K.P.: Archs Biochem. Biophy's. 111, $583(1965)$; 8) Darrow, R.A. ANd Colowick, S.P.: Methods in Enzymology, Edited by Colowick, S.P. And KaPLan, N.O., Vol. 5, p. 226, Academic Press, New York and London (1962); 9) De Grandis, E.: Rass. Med. Sper. 16, 43 (1969); 10) NagATOMO, T. AND AI/AWA, Y.: Folia pharmacol. japon. 67, 166 (1971) (in Japanese): 11) Bahr, G.F. ANd ZeITLeR, E.: J. cell Biol. 15, 489 (1962); 12) Lehninger, A.L.: Physiol. Res. 42, 467 (1962): 13) LeHininger, A.L.: The Mitochondrion, p. 180, W.A. Benjamin Inc., New York and Amsterdam $(1964)$; 14) LeHninger, A.L.: The Mitochondrion, p. 205, W.A. Benjamin Inc., New York and Amsterdam (1964): 15) LfHninger, A.L.: The Mitochondrion, p. 234, W.A. Benjamin Inc., New York and Amsterdam (1964)

\section{DIFFERENT PATTERNS OF INHIBITION OF DOPAMINE-3-HYDROXYLASE BY CYSTEINE}

\author{
Hiroshi IZUMI, Hideko OYAMA, Makoto HAYAKARI \\ and Hikaru OZAWA \\ Pharmaceutical Instirute, Tohohu University, Aobayama, Sendai 980, Japan
}

Accepted December 18, 1975

It has previously been reported (1) that dopamine-, 3 -hydroxylase [DBH : 3,4-dihydroxyphenethylamine, ascorbate- $\mathrm{O}_{2}$ oxidoreductase (hydroxylating), EC 1.14.2.1] was inhibited 
by sulfhydryl compounds such as cysteine, glutathione and coenzyme $A$ and that the inhibition of $\mathrm{DBH}$ by these sulfhydryl compounds was restored by the addition of sulfhydryl type reacting reagents such as N-ethylmaleimide (NEM). However, when the partially purified dopamine- $\beta$-hydroxylase (PDBH) preparation was pretreated with cysteine, we found that the inhibition of DBH activity was not reversed by the addition of NEM or by a dialysis of the cysteine-PDBH preparation although the extent of the inhibition of DBH activity was dose dependent. In this note, we wish to report the inhibitory effect of cysteine on PDBH from the adrenal medulla of bovines.

DBH was purified from beef adrenal glands according to the procedure of Foldes $\mathrm{cl}$ at. (2). In these studies the enzyme obtained at the stage of DEAE-cellulose chromatography elute was used. DBH activity was assayed by the conversion of tyramine to norsynephrine according to the procedure of Van der Schoot et al. (3). Reaction mixture contained in $1.0 \mathrm{ml}$ : potassium phosphate buffer (pH 5.5) 100 //moles, ascorbic acid 10 //moles, fumaric acid $10 / /$ moles, tyramine hydrochloride $10 / /$ moles, catalase 200 Sigma unit, and the enzyme. The reaction mixture was preincubated at $37^{\circ} \mathrm{C}$ for $5 \mathrm{~min}$. The incubation was started by the addition of substrate, and carried out for 15 min at $37^{\circ} \mathrm{C}$ in air. The reaction was terminated by adding $2 \mathrm{ml}$ of $4 \mathrm{~N}$ ammonium hydroxide. The amounts of norsynephrine formed were determined by the conversion of norsynephrine to $p$-hydroxybenzaldehyde by adding periodate, followed by determination of this product by measuring the absorbance at $330 \mathrm{~m} / \%$. The formation of norsynephrine from tyramine under these conditions preceeded lineally for $20 \mathrm{~min}$ and was also proportional to the amount of enzyme used.

The effect of the inclusion of cysteine in enzymic reaction mixture in the absence and the presence of NEM is illustrated by Fig. $1 \AA$. It can be concluded from these data that the $\mathrm{DBH}$ activity was progressively reduced by increasing cysteine concentration in the absence of NEM, whereas these inhibitions were reversed by the addition of equimolar concentration

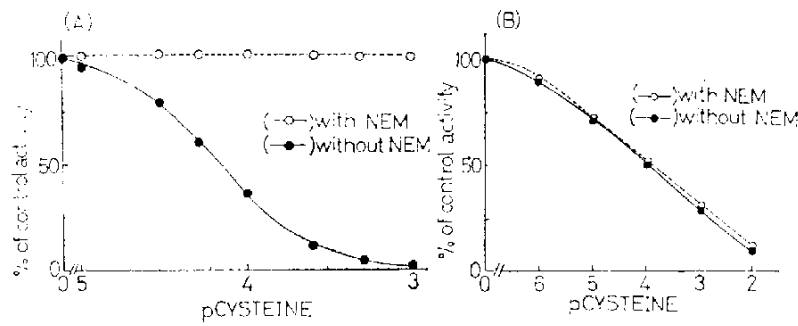

Fic;. 1. (A): Etrect of N-ethylmaleimide (NEM) on cysteine inhibition of dopamineS-hydroxylase. Samples were preincubated for 5 min and incubated for 15 min. $\mathrm{DBH}$ activities were assayed in the absence and the presence of NEM at a collcentration equivalent to the concentration of cysteine.

(B): Effect of $\mathrm{N}$-ethylmaleimide (NEM) on cysteine-pretreated dopamine- ${ }^{;}-$ hydroxylase. PDBH preparation was pretreated with cysteine of various concentrations for $10 \mathrm{~min}$ at $37 \mathrm{C}$. An aliquot was then measured for DBH activitics in the absence and the presence of NI:M al a concentration eguivatent wh the concentration of cysteine.

The term pCYSTIENE is defined as negative logatithm of molat concentration of cystcinc. 
of NEM. These results are in agreement with previous findings by Nagatsu et al. (1). However, when the PDBH preparation was pretreated with cysteine for 10 min at $37^{\circ} \mathrm{C}$, and an aliquot of the mixture was assayed for enzymic activity in the absence and the presence of NEM, the restoration of the cysteinc-induced inhibition of DBH was not observed by the addition of equimolar concentrations of NEM (Fig. 1B). As can be seen in Figs. 1A and 1B, NEM affected the cysteine inhibition of DBH in different ways. These results suggest that different mechanisms are responsible for the inhibitory effect of cysteine.

We also investigated the possibility of reversibility of the inhibition of cysteine-pretreatment DBH by removing cysteine by dialysis. The PDBH preparation was pretreated with cysteine for $10 \mathrm{~min}$ at $37^{\circ} \mathrm{C}$, then dialyzed against 200 volumes of $0.05 \mathrm{M}$ phosphate buffer, $\mathrm{pH} 6.5$ at $4 \mathrm{C}$ for $24 \mathrm{hr}$. The buffer was changed three times under dialysis, and then, an aliquot of the mixture was assayed for DBH activity in the presence of substrate in the range of 1.25-10 mM. The results are shown in Fig. 2. As can be seen, the decrease in DBH activity did not recover by dialysis. Since the observed $\mathrm{Km}$ value $(0.83 \mathrm{mM})$ for substrate is unaltered by the cysteine pretreatment (Fig. 2, inset), it seems likely that the mechanism responsible for the inhibition of DBH activity by cysteine pretreatment is not associated with the decrease of the affinity of the enzyme for substrate.

Inhibition of DBH by binding of the enzyme Cu has been suggested for several sulfurcontaining compounds: diethyldithiocarbamate and disulfiram (4), thiourea derivatives (5, 6), dimethyldithiocarbamate (7), D-cystcine, L-cysteine, mercaptoethanol and coenzymc A (1). As shown above, the cysteine-pretreated inhibition of DBH was not reversed by the addition of NEM (Fig. IB), by dialysis of the cysteine-PDBH preparation (Fig. 2) or by the addition of $\mathrm{Cu}^{+}{ }^{+}$(data not shown), suggesting that the mechanism of this inhibition of DBH by cysteine would not be through the binding of the $\mathrm{Cu}$ of $\mathrm{DBH}$. From the present data and previously reported observations $(1,8)$, it might be reasonable to consider that

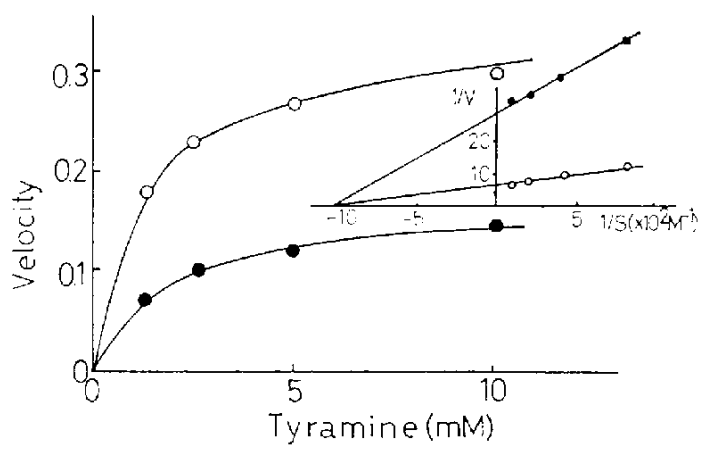

Hici, 2. Eflect of dialysis of cysteine-pretreated dopamine-;-hydroxylase on kinetic parameter. PDBH preparation was pretreated with cystcinc for 10 min at $37^{\circ} \mathrm{C}$, and, after dialyzed the mixture, DBH activities were assayed in the presence of various concentrations of lyramine (final cysteine concentration, $10^{-4} \mathrm{M}$ ). line Weaver-Burk plots (inset) of tyramine concentration against rate of hydroylation with native (-., -) and cysteine-pretreated (-O) enzymes. The selocity is expressed as moles of norsynephrine formed per 15 min. 
the inactivation of $\mathrm{DBH}$ by cysteine in the absence of catalase is due to hydrogen peroxide $\left(\mathrm{H}_{2} \mathrm{O}_{2}\right)$ rather than cysteine itself. The result in Fig. 2 also suggests that modification of the maxinum velocity to tyramine may be sinply due to the destruction of a part of active DBH. However, precise mechanism of the inhibition remains unknown.

In the presence of the naturally occurring inhibitors, DBH can become the rate-limiting enzyme of biosynthesis of norepinephrine (9). The purification and characterization of such inhibitors from various tissues of different species have been investigated in various laboratories $(2,10-15)$. In the process of studying the properties of the naturally occurring inhibitors of DBH $(13,14)$, we observed that the mechanism of inhition of $\mathrm{DBH}$ by the naturally occurring inhibitors seems to be similar to that of the cysteine inhibition, and that thesc inhibitors seem to have sulfhydryl groups in the molecule. In view of the present finding and of wide distribution of the naturally occurring inhibitors in animal tissues (13, 14), it was suggested that these inhibitors might inhibit the DBH irreversibly in vivo and play an important role in the regulation of norepinephrine synthesis. Further investigation is underway to determine the mechanism of the irreversible inhibition of DBH by cysteine pretreatment.

\section{REFERENCES}

1) Nagarsu, T., Klzuya, H. and Hidaka, H.: Biochim. Biophys. Acta. 139, 319 (1967); 2) Foldes, A., Jefferex, P.L., Prestox, B.N. and Alstiv, L.: Biochem. I., 126, 1209 (1972): 3) Van der Schoot, J.B., Creyeling, C.R., Nagaisu, T. and Udfnfrifnd, S.: J. Pharmacol. exp. Ther., 141, 74 (1963): 4) Cioldstein, M., LAUber, E. ANd Makertgian, M.R.: . hiol. Chem., 240, 2066 (1965); 5) Johnsov, G.A., Boukma, S.J. and Kim, E.G.: J. Pharmacot. exp. Ther., 168, 229 (1969): 6) OYama, H., l7umi, H. AND Olawa, H.: Biochem. Pharmacol., 25, 277 (1976): 7) Lippman, N. AVD l.toyd, K.: Biochem. Pharmacol., 18, 2507 (1969): 8) KuzUYa, H.: J. Wate med. Ass., 19, 401 (1967): 9) Crfveling, C.R., Daly, J., Witkop, B. And LidinfRiend, S.: Biochim. Biophys. Acta, 64, 125 (1962); 10) Austin, L., Livfti, B.G. and ChubB, I.W.: Circulation Res, Stuppl, $10($ III) 111(1967): 11) Duch, D.S., Viviros, O.H. AND KiNerrSH N.: Biochem. Phamacol. 17, 255 (1968); 12) DLCH, D.S. Avi KIRSHnfr, N.: Biochem. Biophys. Acta, 236, 628 (1971): 13) OYama, H., Izum, H. And OzAwa, H.: Yakugahu Zasshi 95, 621 (1975) (in Japanese): 14) Izum, H., Oyama, H. and Ozawa, H.: Chem. Pharm. Bull., Tokyo, 23, 2362 (1975): 15) Harralson, J.D. ANd Brown, F.C.: Proc. Soc. exp. Biol Med. 149. 643 (1975) 